\title{
NOTE
}

\section{Cadmium uptake and trophic transfer in coastal plankton under contrasting nitrogen regimes}

\author{
Wen-Xiong Wang*, Robert C. H. Dei, Yan Xu \\ Department of Biology, The Hong Kong University of Science and Technology (HKUST), Clear Water Bay, Kowloon, \\ Hong Kong, China
}

\begin{abstract}
Biological processes (uptake, trophic transfer, regeneration/excretion, and decomposition) are critical in controlling the fate of bioactive metals in the ocean. Whether nutrient conditions can affect metal uptake in marine phytoplankton and its subsequent trophic transfer along planktonic food chains is little known. We demonstrate that Cd accumulation in marine diatoms is dependent on ambient nitrogen conditions and thus the physiological status of phytoplankton cells. Diatom cells Thalassiosira pseudonana and T. weissflogii inoculated under nitrogen-limited conditions accumulated considerably less $\mathrm{Cd}$ than cells maintained under nitrogen-enriched conditions. The intracellular partitioning of $\mathrm{Cd}$ in the diatoms was also positively related to the level of ambient N. Phosphate and silicate starvation did not affect $\mathrm{Cd}$ uptake in diatoms. The trophic transfer, quantified by measurement of the Cd assimilation efficiency (AE) from ingested diatoms in copepods Calanus sinicus, increased with an increase in the $\mathrm{N}$ quota of the diatom cells maintained in a semi-continuous culture. AEs were however comparable in copepods feeding on $\mathrm{N}$-starved and $\mathrm{N}$-enriched diatoms. There was a linear relationship between the $\mathrm{Cd} \mathrm{AE}$ and the $\mathrm{Cd}$ distribution in the cytoplasm of diatoms. The Cd regeneration rate in copepods was independent of the $\mathrm{N}$ status of ingested diatoms. Our study suggests that the cycling of $\mathrm{Cd}$ in marine planktonic food chains may be depressed under nitrogen-limited conditions. Conversely, nitrogen enrichment leads to an increase in Cd uptake in phytoplankton cells and zooplankton, elevating the potential exposure of plankton to toxic metals. Thus, nitrogen-stimulated eutrophication may not only affect the cycling of carbon, nitrogen and phosphorus in aquatic ecosystems, but can also result in changes in the cycling of toxic metals in marine food webs.
\end{abstract}

KEY WORDS: Cadmium - Uptake $\cdot$ Trophic transfer $\cdot$ Nutrients · Biogeochemical cycling

Resale or republication not permitted without written consent of the publisher

Understanding the fate of trace metals and their interaction with marine plankton is essential to our knowledge of metal biogeochemistry in oceanic and coastal waters. Previous studies on the bioavailability

*E-mail: wwang@ust.hk (or uptake) of metals to marine phytoplankton have mainly focused on the control exerted by metal aqueous chemistry (Campbell 1995). Geochemical and biological processes (metal speciation, metal-metal antagonistic interaction, such as the Cd-Zn-Mn system), and environmental factors $\left(\mathrm{pCO}_{2}\right)$ are known to greatly affect $\mathrm{Cd}$ uptake in marine phytoplankton (Sunda 1994, Hare \& Tessier 1996, Sunda \& Huntsman 1996, Cullen et al. 1999). Biochemical processes leading to metal sequestration include the production of extracellular chelating compounds or porphyrin complexes (Moffett \& Brand 1996, Hutchins et al. 1999b). Recent studies have also indicated that the $\mathrm{pCO}_{2}$ in the ambient water is critical for the uptake of $\mathrm{Cd}$ and $\mathrm{Zn}$ by marine phytoplankton (Morel et al. 1994, Cullen et al. 1999). However, little is known about the interactions between nutrient and metal uptake in marine phytoplankton and their potential impacts on metal trophic transfer in planktonic food chains. There is only limited knowledge on the influence of coastal eutrophication on the uptake of metals by aquatic organisms (Currie et al. 1998, Rijstenbil et al. 1998, Wang \& Dei 2001).

Coastal eutrophication has been reported in many aquatic systems impacted by human activity (Smith et al. 1999). Considerable evidence indicates that coastal eutrophication has affected the cycling of carbon, nitrogen and phosphorus in these systems (Vitousek et al. 1997, Smith et al. 1999). Whether nutrient enrichment has affected the biological cycling of toxic metals remains essentially unknown. Circumstantial evidence suggests an interaction between macronutrients and trace metals in affecting the ecosystem dynamics (Breitburg et al. 1999). This interaction appears to be non-additive, i.e., the addition of trace elements greatly decreases the response of phytoplankton to macronutrient addition in mesocosm experiments (Breitburg et al. 1999).

In this study, we examined the influence of macronutrients on the biological uptake, trophic transfer and 
regeneration of $\mathrm{Cd}$ in coastal plankton. $\mathrm{Cd}$ is both a toxic metal and a tracer of paleo-phosphate concentration in surface water, although a recent study has suggested that the $\mathrm{Cd}: \mathrm{P}$ ratio in phytoplankton is dependent on the ambient $\mathrm{pCO}_{2}$, which may complicate the use of $\mathrm{Cd}$ as a tracer of paleo-phosphate concentration (Cullen et al. 1999). Our objectives were to examine the Cd uptake in diatoms influenced by macronutrient starvation or different levels of $\mathrm{N}$ enrichment. We further determined the assimilation efficiency (AE) and regeneration rate of $\mathrm{Cd}$ in marine copepods feeding on diatoms inoculated under different $\mathrm{N}$ conditions. AE is an important physiological parameter determining the trophic transfer of metals in marine food chains (Wang \& Fisher 1999).

Materials and methods. Metal uptake in diatom cells: Two axenic cultures of coastal diatoms, Thalassiosira pseudonana (Clone $3 \mathrm{H}$ ) and T. weissflogii (CCMP 1048), were used in the experiments. The cells were maintained in an f/2 medium (Guillard \& Ryther 1962) at $18^{\circ} \mathrm{C}$ under a light illumination of $100 \mu \mathrm{E} \mathrm{m} \mathrm{m}^{-2} \mathrm{~s}^{-1}$ with a 14:10 h light:dark cycle. The seawater used in all experiments was collected $10 \mathrm{~km}$ off East Hong Kong, remote from any anthropogenic activity. ${ }^{109} \mathrm{Cd}$ was used as a tracer for the uptake of stable Cd into the cells. Radioisotope addition corresponded to a Cd concentration of $2 \mathrm{nM}$. All nutrient stocks were prepared by being passed through a Chelex ion exchange resin to remove trace metals. All uptake experiments were conducted in $150 \mathrm{ml}$ of $0.2 \mu \mathrm{m}$-filtered seawater maintained at $18^{\circ} \mathrm{C}$, and held in acid-cleaned polycarbonate bottles under a light illumination of $100 \mu \mathrm{E} \mathrm{m} \mathrm{m}^{-2} \mathrm{~s}^{-1}$. Cd uptake in the diatoms was determined over a shortterm exposure period, during which time there was a negligible decrease of nutrient concentration in the ambient water. The cells inoculated under different nutrient conditions were collected onto $3 \mu \mathrm{m}$ polycarbonate membranes, rinsed, and resuspended in $<0.2 \mu \mathrm{m}$-filtered seawater. The cells were then added to $150 \mathrm{ml}$ of filtered seawater containing $18 \mathrm{nM}$ of $\mathrm{Cd}$ and different additions of nutrients. Cell density in the medium was between 3 and $5 \times 10^{5}$ cells $\mathrm{ml}^{-1}$ for $T$. pseudonana, and $10^{5}$ cells $\mathrm{ml}^{-1}$ for $T$. weissflogii. In each experiment, cell density was maintained at a similar level among the different treatments. At time intervals of 1, 2, 3 and $5 \mathrm{~h}$, a $10 \mathrm{ml}$ aliquot was filtered onto a $1 \mu \mathrm{m}$ polycarbonate membrane, rinsed with filtered seawater, and the radioactivity of the cells counted. To measure the dry weight of the cells, the cells were filtered onto a pre-weighed glass-fiber filter, rinsed with ammonium formate, and dried at $80^{\circ} \mathrm{C}$ for $1 \mathrm{~d}$. The protein content of the cells was measured using the bicinchoninic acid (BCA) method. Intracellular distribution of Cd was measured by the Ti washing technique (Hudson \& Morel 1989, Hutchins et al. 1999a). The radioactivity of ${ }^{109} \mathrm{Cd}$ was determined on a Wallac Wizard $1480 \mathrm{NaI}$ gamma detector at $88 \mathrm{keV}$. Counting times were adjusted to result in propagated counting errors of $<3 \%$.

Three experiments were conducted to determine the influence of macronutrients on the Cd uptake in diatoms. Only the experimental macronutrient was added in the medium for Cd uptake measurement. The first experiment was designed to compare the uptake of $\mathrm{Cd}$ in nutrient-starved and nutrient-enriched cells. Diatom cells in the late exponential growth phase were filtered and starved of nitrate for $3 \mathrm{~d}$, phosphate for $3 \mathrm{~d}$, or silicate for $1 \mathrm{~d}$ before the experiments. The cells did not grow following these treatments, indicating that they were under starvation for a specific nutrient. Other macronutrients were added during the starvation of 1 specific nutrient. In another treatment (enriched cells), exponentially growing cells were transferred to nutrient-enriched water $(882 \mu \mathrm{M}$ of nitrate, $36.2 \mu \mathrm{M}$ of phosphate, and $105.6 \mu \mathrm{M}$ of silicate) for $2 \mathrm{~d}$. Both the 'starved' and the 'enriched' cells were then suspended in either nutrient-'depleted' or -'enriched' filtered seawater for Cd uptake measurements. The second experiment was designed to compare the Cd uptake in diatoms at different ambient nitrate concentrations. The late exponentially growing diatom cells inoculated in a full $\mathrm{f} / 2$ nutrient medium were transferred to different nitrate concentrations $(17.6,58.7$, and $176 \mu \mathrm{M})$ for $1.5 \mathrm{~d}$, during which time the initial $\mathrm{N}$ concentrations declined by 20 to $60 \%$, before the Cd uptake measurements were made at these nitrate concentrations. The third experiment was designed to compare the Cd uptake in diatoms maintained in semi-continuous cultures. Diatom cells were inoculated at $2 \mathrm{~N}$ levels (17.6 and $176 \mu \mathrm{M})$, and were transferred to a new medium containing the same concentration of $\mathrm{N}$ when they reached the mid-exponential growth phase. After 5 transfers, the cells underwent $>10$ divisions and $\mathrm{Cd}$ uptake was subsequently measured at these $2 \mathrm{~N}$ levels.

Cd assimilation efficiency in copepods: Diatom cells (Thalassiosira weissflogii) were inoculated in a semicontinuous culture at 2 different nitrate levels (17.6 and $176 \mu \mathrm{M}$ ) and radiolabeled with ${ }^{109} \mathrm{Cd}$, as described in Wang \& Fisher (1996, 1998a). Additions of other nutrients were $\mathrm{f} / 2$ levels for $\mathrm{P}, \mathrm{Si}$, and vitamins, and $\mathrm{f} / 20$ levels for $\mathrm{Mn}, \mathrm{Co}, \mathrm{Fe}$, and Mo. After 1 more transfer (in the presence of ${ }^{109} \mathrm{Cd}$ ) when the cells reached the exponential phase, the cells were collected before being fed to the copepods Calanus sinicus. In another experiment, the diatoms T. pseudonana and T. weissflogii were inoculated in $\mathrm{f} / 2$ levels of macronutrients and radiolabeled with ${ }^{109} \mathrm{Cd}$. When the cells reached the late exponential growth phase, they were collected and divided into 2 groups. One group was subjected to $\mathrm{N}$ starvation for $3 \mathrm{~d}$ (but in the presence of other 
macronutrients), whereas the other group was enriched with an f/2 level of nitrate and other macronutrients for $2 \mathrm{~d}$. The cells were then collected by filtration before being fed to the copepods.

The radiolabeled diatoms were pulse-fed to the copepods for $20 \mathrm{~min}$ at a cell density of $20000 \mathrm{cells} \mathrm{ml}^{-1}$ and a copepod density of 0.2 copepods $\mathrm{ml}^{-1}$ using methods described in Wang \& Fisher (1998a, 1999). The copepods had originally been collected by net towing $(500 \mu \mathrm{m})$ from Clear Water Bay, Hong Kong, and were acclimated in the laboratory for $1 \mathrm{~d}$ in the presence of diatom diets. After the pulse radioactive feeding, the copepods were removed with a mesh and their radioactivity was immediately counted for $2 \mathrm{~min}$. Any feces produced during the radioactive feeding period were also collected and radioassayed. The total amount of ${ }^{109} \mathrm{Cd}$ ingested was calculated as the sum of the radioactivity in the copepods and the radioactivity in egested feces after $20 \mathrm{~min}$ of pulse feeding. The copepods were subsequently depurated in nonradioactive waters for $2 \mathrm{~d}$ in the presence of the same diatom diet. The radioactivity retained in the copepods was determined at time intervals. The AE and regeneration rate were calculated as the $y$-intercept and the slope of the linear regression between the natural log of the percentage of $\mathrm{Cd}$ retained in copepods and the time of depuration (between 12 and $48 \mathrm{~h}$ ), respectively (Wang \& Fisher 1998a, 1999). The fraction of Cd in the algal cytoplasm was measured as described in Fisher et al. (1983) and Reinfelder \& Fisher (1991).

Results and discussion. Nitrate starvation significantly reduced the uptake of $\mathrm{Cd}$ in the Thalassiosira spp. cells (Fig. 1). The uptake rate, calculated from the slope of $\mathrm{Cd}$ accumulation in diatom cells against exposure time ( 1 to $5 \mathrm{~h}$ ), was about 4 times higher in diatom cells inoculated in $\mathrm{N}$-enriched medium $(176 \mu \mathrm{M})$ than in cells starved of $\mathrm{N}$ for $3 \mathrm{~d}$ ( $\mathrm{p}<0.05$, Student's $t$-test). When the $\mathrm{N}$-starved cells were resuspended in $\mathrm{N}$ enriched seawater $(176 \mu \mathrm{M})$, there was no immediate increase in Cd uptake, indicating no surge uptake as commonly found for ammonium and urea (Goldman \& Gilbert 1982, Cochlan \& Harrison 1991). Similarly, when the $\mathrm{N}$-enriched cells were resupended in $\mathrm{N}$ depleted seawater, there was no immediate decline in $\mathrm{Cd}$ uptake within the short exposure period. In contrast, $\mathrm{P}$ and Si starvation did not significantly influence $\mathrm{Cd}$ uptake in the cells. After $5 \mathrm{~h}$ exposure, about $80 \%$ of the diatoms' $\mathrm{Cd}$ was in the intracellular pool in $\mathrm{N}$ enriched cells, whereas only $25 \%$ of the Cd was in the intracellular pool in N-starved cells. About 74 to $84 \%$ of the Cd was found in the intracellular compartment in both P- and Si-starved and enriched cells after $5 \mathrm{~h}$ exposure.

When the 2 diatoms (in the late exponential growth phase) were acclimated to 3 nitrate levels for only
$1.5 \mathrm{~d}$, the Cd uptake measured in these cells was significantly reduced, with a decrease in $\mathrm{N}$ concentration in both species ( $\mathrm{p}<0.05,1$-way ANOVA) (Fig. 2). The uptake rate was 4.0 to 4.6 times higher at $176 \mu \mathrm{M}$ than at $17.6 \mu \mathrm{M}$ for both diatoms. In this experiment, we did not quantify the intracellular distribution of $\mathrm{Cd}$.

These results were further confirmed by experiments using cells inoculated in a semi-continuous culture. In this experiment, Cd uptake was also significantly enhanced with increasing $\mathrm{N}$ concentration ( $\mathrm{p}<$ $0.01, t$-test, Fig. 3). The calculated uptake rate was 4.1 times higher at $176 \mu \mathrm{M}$ than at $17.6 \mu \mathrm{M}$. The cell dry weight was 1.2 times higher at $176 \mu \mathrm{M}$ than at $17.6 \mu \mathrm{M}$. At $5 \mathrm{~h}, 80 \%$ of the diatoms' Cd was found in the intracellular compartment in cells maintained at $176 \mu \mathrm{M}$ compared to $42 \%$ in cells maintained at $17.6 \mu \mathrm{M}$. At $24 \mathrm{~h}, 94 \%$ of the Cd was found in the intracellular pool at $176 \mu \mathrm{M}$ compared to $72 \%$ at $17.6 \mu \mathrm{M}$.

These experiments therefore demonstrated that $\mathrm{Cd}$ uptake in phytoplankton cells is strongly related to the ambient $\mathrm{N}$ level, and add an important dimension to our current understanding of the processes controlling $\mathrm{Cd}$ uptake in marine phytoplankton. In our experi-

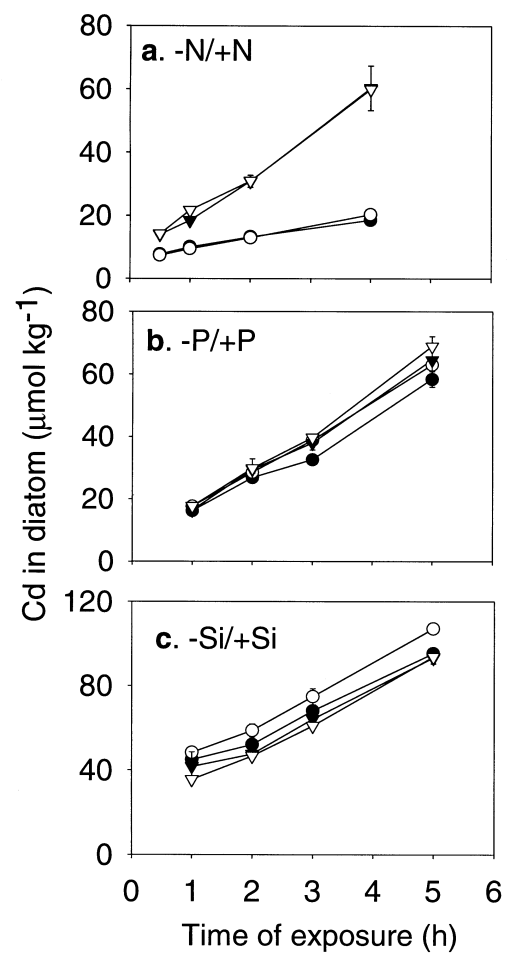

Fig. 1. Thalassiosira pseudonana. Cd uptake in diatoms inoculated under nutrient-starved and nutrient-enriched conditions. (๑) Nutrient-starved cells in nutrient-depleted water; (O) nutrient-starved cells in $176 \mu \mathrm{M}$ nitrate, $18.1 \mu \mathrm{M}$ phosphate, or $26.4 \mu \mathrm{M}$ silicate; $(\boldsymbol{\nabla})$ nutrient-enriched cells in nutrient-depleted water; $(\nabla)$ nutrient-enriched cells in $176 \mu \mathrm{M}$ nitrate, $18.1 \mu \mathrm{M}$ phosphate, or $26.4 \mu \mathrm{M}$ silicate. Data are means $\pm \mathrm{SD}(\mathrm{n}=2)$ 


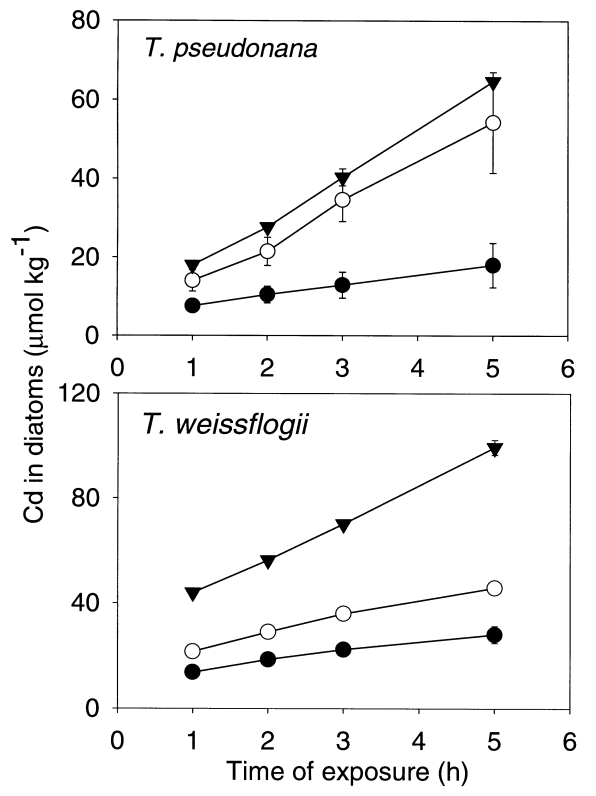

Fig. 2. Thalassiosira pseudonana and Thalassiosira weissflogii. Cd uptake in 2 diatoms following inoculation at different nitrate levels for $1.5 \mathrm{~d}$. (๑) Cells maintained at $17.6 \mu \mathrm{M}$ nitrate; $(O)$ cells maintained at $58.7 \mu \mathrm{M}$ nitrate; $(\boldsymbol{\nabla})$ cells main-

tained at $176 \mu \mathrm{M}$ nitrate. Data are means $\pm \mathrm{SD}(\mathrm{n}=2)$

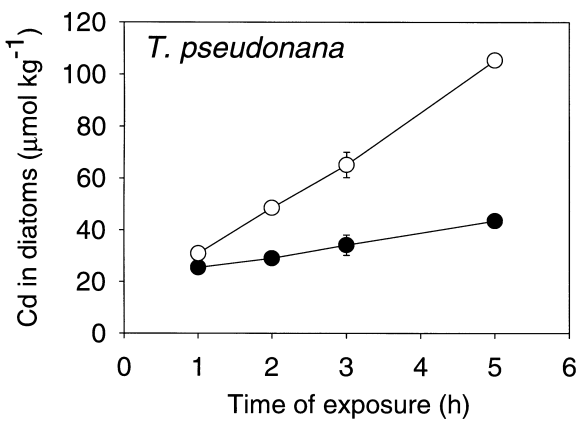

Fig. 3. Thalassiosira pseudonana. Cd uptake in diatoms inoculated at 17.6 and $176 \mu \mathrm{M}$ nitrate in semi-continuous culture. (•) Cells maintained at $17.6 \mu \mathrm{M}$ nitrate; (O) cells maintained at $176 \mu \mathrm{M}$ nitrate. Data are means $\pm \mathrm{SD}(\mathrm{n}=2)$ ments, we also found that, similarly to earlier studies (Harrison et al. 1990, Wang \& Fisher 1996), the protein concentration in the cells increased with increasing $\mathrm{N}$ concentration (Table 1). It is likely that the concentration of ligands (e.g., phytochelatins: Ahner et al. 1995) available for $\mathrm{Cd}$ binding, transport and sequestration increases with increasing $\mathrm{N}$ levels, leading to an enhanced Cd uptake into the cells. In our study, we did not quantify the carbonic anhydrase activity in cells maintained under different $\mathrm{N}$ conditions, which has been recently shown to have $\mathrm{Cd}$ as a co-factor (Cullen et al. 1999). Alternatively, the increase in Cd uptake may be due to an increase in the cell growth rate arising from nitrate addition. Circumstantial evidence has indicated that cell growth may control Cd uptake. For example, Luoma et al. (1998) observed a significant increase in $\mathrm{Cd}$ concentration in a phytoplankton assemblage during blooms in San Francisco Bay. Our recent study also demonstrated that there was a significant correlation between Cd uptake and cell growth rate in different species of marine phytoplankton (Wang \& Dei 2001). However, whether the cell growth rate directly affects $\mathrm{Cd}$ uptake in marine phytoplankton remains to be determined.

The interaction between nutrient and metal uptake of phytoplankton may have important implications for metal cycling in coastal and oceanic waters. The low biological uptake in phytoplankton cells under nitrogen-limited conditions suggests that the biological transport of $\mathrm{Cd}$ in marine planktonic food chains would be limited. Conversely, nitrogen enrichment (e.g., coastal eutrophication) may considerably enhance the Cd concentration in phytoplankton cells, and thereby exaggerate the potential toxicity of metals to phytoplankton. This was not tested in our study. An alternative argument would be that $\mathrm{N}$-enriched cells are able to accumulate more intracellular detoxifying ligands than N-starved cells; consequently, toxicity could actually decrease despite the increased Cd uptake. Furthermore, the dependence of $\mathrm{Cd}$ uptake on ambient

Table 1. Calanus sinicus. Calculated assimilation efficiencies (AE) and regeneration rate constants of Cd in marine copepods feeding on diatoms inoculated under different nitrates conditions. Data are means \pm SD (n = 2 to 3 ). Only 1 measurement of protein was made in each treatment

\begin{tabular}{|c|c|c|c|c|c|c|}
\hline & \multicolumn{2}{|c|}{ Thalassiosira pseudonana } & \multicolumn{2}{|c|}{ Thalassiosira weissflogii } & \multicolumn{2}{|c|}{ Thalassiosira weissflogii } \\
\hline & N starvation & $\mathrm{N}$ enrichment & N starvation & N enrichment & $17.6 \mu \mathrm{M}$ nitrate & $176 \mu \mathrm{M}$ nitrate \\
\hline $\begin{array}{l}\text { Cd in diatom } \\
\text { cytoplasm }(\%)\end{array}$ & $39.1 \pm 1.4$ & $41.0 \pm 0.2$ & $71.0 \pm 0.4$ & $68.9 \pm 1.8$ & $25.6 \pm 1.0$ & $46.2 \pm 0.4$ \\
\hline $\mathrm{Cd}$ AE (\%) & $40.2 \pm 3.5$ & $41.2 \pm 2.9$ & $90.4 \pm 3.4$ & $98.1 \pm 1.3$ & $21.4 \pm 3.5$ & $52.2 \pm 2.2$ \\
\hline $\begin{array}{l}\text { Cd regeneration } \\
\text { rate constant }\left(\mathrm{d}^{-1}\right)\end{array}$ & $0.470 \pm 0.042$ & $0.483 \pm 0.055$ & $0.923 \pm 0.039$ & $1.087 \pm 0.078$ & $0.630 \pm 0.032$ & $0.668 \pm 0.066$ \\
\hline $\begin{array}{l}\text { Protein content } \\
\left(\mathrm{pg} \mathrm{cell}^{-1}\right)\end{array}$ & 2.85 & 4.63 & 49.3 & 60.7 & 40.3 & 49.4 \\
\hline
\end{tabular}




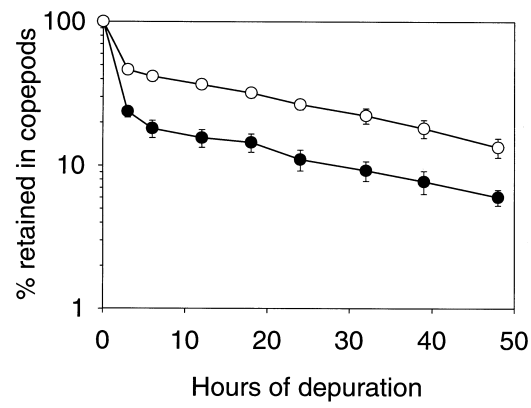

Fig. 4. Calanus sinicus. Depuration of ingested ${ }^{109} \mathrm{Cd}$ in marine copepods following pulse ingestion of diatoms Thalassiosira weissflogii inoculated at 2 different nitrate levels in a semi-continuous culture. (•) Cells inoculated at $17.6 \mu \mathrm{M}$ nitrate; (O) cells inoculated at $176 \mu \mathrm{M}$ nitrate. Data are means $\pm \mathrm{SD}(\mathrm{n}=3)$

nitrate concentration but not on phosphate concentration suggests that the $\mathrm{Cd} / \mathrm{P}$ ratio in surface waters can be affected by the nitrate concentration in addition to the $\mathrm{CO}_{2}$ partial pressure (Cullen et al. 1999).

The transfer of $\mathrm{Cd}$ in marine copepods Calanus sinicus was determined by measurements of $\mathrm{Cd} \mathrm{AE}$ in cells inoculated at 2 nitrate concentrations in a semicontinuous culture. In this experiment, copepods depurated $\mathrm{Cd}$ at a faster rate following a pulse ingestion of ${ }^{109} \mathrm{Cd}$-labeled $\mathrm{N}$-poor diatoms than they did following a pulse ingestion of N-enriched diatoms (Fig. 4). The calculated Cd AEs were 2.4 times higher in individuals fed with diatoms inoculated at $176 \mu \mathrm{M}$ than in those fed with diatoms inoculated at $17.6 \mu \mathrm{M}$ (Table 1). Moreover, in this experiment, we found that the distribution of $\mathrm{Cd}$ in the diatom cytoplasm, which critically affects metal assimilation in marine copepods (Reinfelder \& Fisher 1991, Hutchins et al. 1995), was also 1.8 times higher for diatoms inoculated at $176 \mu \mathrm{M}$ than for diatoms inoculated at $17.6 \mu \mathrm{M}$ (Table 1). The ingestion activity of copepods was comparable for $\mathrm{N}$-enriched


(23000 cells $\mathrm{h}^{-1}$ copepod $^{-1}$ ). The regeneration rate of $\mathrm{Cd}$ (long-term physiological turnover rate) was however independent of the nutritional status of the cells ingested, but was relatively high $\left(0.632\right.$ to $0.668 \mathrm{~d}^{-1}$ for both treatments) and comparable to earlier studies (Wang \& Fisher 1998a,b). This experiment suggested that Cd assimilation but not regeneration in copepods is controlled by the $\mathrm{N}$ quota of food particles, in contrast to the finding for marine mussels (Wang \& Fisher 1996).

Comparable depuration was however found in copepods feeding on $\mathrm{N}$-starved and $\mathrm{N}$-enriched diatoms (data not shown). Although there was more Cd in the intracellular compartment in $\mathrm{N}$-enriched diatoms than in $\mathrm{N}$-starved diatoms during the short-term exposure period, there was no major difference in $\mathrm{Cd}$ distribution in the diatoms' cytoplasm between the 2 treat- ments (Table 1). This was probably due to the fact that ${ }^{109} \mathrm{Cd}$ was radiolabeled onto the diatoms before the cells were transferred for $\mathrm{N}$ starvation; thus, the metal distribution in diatoms was not greatly influenced by subsequent $\mathrm{N}$ starvation or $\mathrm{N}$ enrichment. The calculated Cd AEs were also comparable between the 2 treatments (Table 1). More Cd was found in the cytoplasm of diatom Thalassiosira weissflogii than in that of T. pseudonana. The measured AEs were $>90 \%$ in copepods feeding on $T$. weissflogii and were considerably higher than in a separate experiment examining the influence of $\mathrm{N}$ level on Cd AEs (21 to $52 \%$ ). There were also considerable differences in the $\mathrm{Cd}$ regeneration rate in copepods among the 3 experiments (Table 1). The difference in the total protein concentration in the diatoms appeared to have no consistent effect on $\mathrm{Cd}$ assimilation in the copepods.

The difference in Cd AEs among different experiments and between the 2 diatoms was primarily accounted for by the difference in $\mathrm{Cd}$ distribution in the cytoplasm of the diatoms. There was a significant linear relationship between the Cd AEs in the copepods and the Cd distribution in diatoms' cytoplasm (Fig. 5). Our study provides further evidence that metal distribution in phytoplankton critically affects the trophic transfer of metals in the marine planktonic food chain (Reinfelder \& Fisher 1991, Hutchins et al. 1995). Previously, only Hutchins et al. (1995) demonstrated a significant relationship between the $\mathrm{AE}$ in copepods and the distribution in the diatoms' cytoplasm for a specific metal such as Fe. Thus, for metals such as Cd, which partitions mostly in the intracellular pool of diatoms, metal desorption within the copepod's gut following food ingestion may not be important in controlling metal assimilation in the copepods.

Metal accumulation in marine copepods is related to the metal influx rate (controlled by metal AE, ingestion activity, and metal concentration in ingested cells) and the metal efflux rate (Reinfelder et al. 1998, Wang \&



Fig. 5. Relationship between Cd assimilation efficiency (AE) in marine copepods Calanus sinicus and its distribution in the cytoplasm of 2 diatoms (Thalassiosira spp.). Data are means $\pm \mathrm{SD}(\mathrm{n}=3$ for $\mathrm{AE}$, and $\mathrm{n}=2$ for cytoplasmic distribution) 
Fisher 1998a). Of the 4 aforementioned parameters, nitrogen limitation or enrichment can affect metal accumulation in marine copepods through its influence on metal uptake in phytoplankton and metal assimilation in copepods. Thus, an increase in $\mathrm{N}$ concentration can lead to an increase in Cd concentration in phytoplankton cells, and further to an increase in Cd influx in marine zooplankton. Our study therefore highlights the dependence of Cd uptake and transfer on environmental nitrogen conditions, which has important implications for our understanding of metal dynamics in coastal waters. Thus, coastal eutrophication may potentially affect metal uptake, toxicity and trophic transfer in aquatic food chains. Given that metal pollution and nutrient enrichment can often occur simultaneously in coastal waters, there is a need to further study the interaction between toxic metals and macronutrients in controlling ecosystem dynamics and function.

Acknowledgements. We thank Drs Phil Rainbow, Samuel Luoma, and John Reinfelder, and anonymous reviewers for their helpful discussions and comments on this work. This work was supported by a CERG/RGC grant (HKUST6137/ 99M) to W.-X.W.

\section{LITERATURE CITED}

Ahner BA, Kong S, Morel FMM (1995) Phytochelatin production in marine algae. I. An interspecies comparison. Limnol Oceanogr 40:649-657

Breitburg DL, Sanders JG, Gilmour CC, Hatfield CA, Osman RW, Riedel GF, Seitzinger SB, Sellner KG (1999) Variability in response to nutrients and trace elements, and transmission of stressor effects through an estuarine food web. Limnol Oceanogr 44:837-863

Campbell PGC (1995) Interactions between trace metals and organisms: critique of the free-ion activity model. In: Tessier A, Turner DR (eds) Metal speciation and bioavailability in aquatic systems. John Wiley, Chichester, p 45-102

Cochlan WP, Harrison PJ (1991) Uptake of nitrate, ammonium, and urea by nitrogen-starved cultures of Micromonas pusilla (Prasinophyceae): transient responses. J Phycol 27: 673-679

Cullen JT, Lane TW, Morel FMM, Sherrell RM (1999) Modulation of cadmium uptake in phytoplankton by seawater $\mathrm{CO}_{2}$ concentration. Nature 402:165-167

Currie RS, Muir DCG, Fairchild WL, Holoka MH, Hecky RE (1998) Influence of nutrient additions on cadmium bioaccumulation by aquatic invertebrates in littoral enclosures. Environ Toxicol Chem 17:2435-2443

Fisher NS, Burns KS, Cherry RD, Heyraud M (1983) Accumulation and cellular distribution of ${ }^{241} \mathrm{Am},{ }^{210} \mathrm{Po}$, and ${ }^{210} \mathrm{~Pb}$ in two marine algae. Mar Ecol Prog Ser 11:233-237

Goldman JC, Gilbert PM (1982) Comparative rapid ammonium uptake by four species of marine phytoplankton. Limnol Oceanogr 27:814-827

Guillard RRL, Ryther JH (1962) Studies on marine planktonic diatoms. I. Cyclotella nana hustedt and Detonula confervacea (Cleve) Gran. Can J Microbiol 8:229-239

Editorial responsibility: Otto Kinne (Editor), Oldendorf/Luhe, Germany
Hare L, Tessier A (1996) Predicting animal cadmium concentrations in lakes. Nature 380:430-432

Harrison PJ, Thompson PA, Calderwood GS (1990) Effects of nutrient and light limitation on the biochemical composition of phytoplankton. J Appl Phycol 2:45-56

Hudson RJM, Morel FMM (1989) Distinguishing between extra- and intracellular iron in marine phytoplankton. Limnol Oceanogr 34:1113-1120

Hutchins DA, Wang WX, Fisher NS (1995) Copepod grazing and the biogeochemical fate of diatom iron. Limnol Oceanogr 40:989-994

Hutchins DA, Wang WX, Schmidt MA, Fisher NS (1999a) Dual-labeling techniques for trace metal biogeochemical investigations in aquatic plankton communities. Aquat Microb Ecol 19:129-138

Hutchins DA, Witter AE, Butler A, Luther GW III (1999b) Competition among marine phytoplankton for different chelated iron species. Nature 400:858-861

Luoma SN, van Geen A, Lee BG, Cloern JE (1998) Metal uptake by phytoplankton during a bloom in South San Francisco Bay: implications for metal cycling in estuaries. Limnol Oceanogr 43:1007-1016

Moffett JW, Brand LE (1996) Production of strong, extracellular $\mathrm{Cu}$ chelators by marine cyanobacteria in response to Cu stress. Limnol Oceanogr 41:388-395

Morel FMM, Reinfelder JR, Roberts SB, Chamberlain CP, Lee JG, Yee D (1994) Zinc and carbon colimitation of marine phytoplankton. Nature 369:740-742

Reinfelder JR, Fisher NS (1991) The assimilation of elements ingested by marine copepods. Science 251:794-796

Reinfelder JR, Fisher NS, Luoma SN, Nichols JW, Wang WX (1998) Trace element trophic transfer in aquatic organisms: a critique of the kinetic model approach. Sci Total Environ 219:117-135

Rijstenbil JW, Dehairs F, Ehrlich R, Wijnholds JA (1998) Effect of the nitrogen status on copper accumulation and pools of metal-binding peptides in the planktonic diatom Thalassiosira pseudonana. Aquat Toxicol 42:187-209

Smith VH, Tilman GD, Nekola JC (1999) Eutrophication: impacts of excess nutrient inputs of freshwater, marine, and terrestrial ecosystems. Environ Pollut 100:179-196

Sunda WG (1994) Trace metal/phytoplankton interactions in the sea. In: Bidoglio G, Stumm W (eds) Chemistry of aquatic systems: local and global perspectives. Kluwer Academic, Boston, MA, p 213-247

Sunda WG, Huntsman S (1996) Antagonisms between cadmium and zinc toxicity and manganese limitation in a coastal diatom. Limnol Oceanogr 41:373-387

Vitousek PM, Mooney HA, Lubchenko J, Melillo JM (1997) Human domination of Earth's ecosystems. Science 277: 494-499

Wang WX, Dei RCH (2001) Effects of major nutrient additions on metal uptake in phytoplankton. Environ Pollut 111: 233-239

Wang WX, Fisher NS (1996) Assimilation of trace elements by the mussel Mytilus edulis: effects of diatom chemical composition. Mar Biol 125:715-724

Wang WX, Fisher NS (1998a) Accumulation of trace elements in a marine copepod. Limnol Oceanogr 43:273-283

Wang WX, Fisher NS (1998b) Excretion of trace elements in marine copepods and its bioavailability to diatoms. J Mar Res 56:713-729

Wang WX, Fisher NS (1999) Assimilation efficiencies of chemical contaminants in aquatic invertebrates: a synthesis. Environ Toxicol Chem 18:2034-2045

Submitted: June 20, 2000; Accepted: September 5, 2000 Proofs received from author(s): January 23, 2001 